\title{
Beyond-root calcium fertilization of apple trees
}

\author{
KAZIMIERZ SLOWIK and DARIUSZ SWIETLIK
}

Institute of Pomology and Floriculture, ul. Pomologiczna 22, 96-100 Skierniewice, Poland

(Received: August 4, 1983)

\begin{abstract}
Investigations were performed in the period 1977-1979 on the apple tree cultivar 'Fantazja', on rootstock A 2, M 7 and MM 106 on the effect of spraying with solution containing calcium on the incidence of bitter pit, breakdown, calcium content in the fruit flesh and other features of the fruits. Threefold spraying with calcium nitrate, calcium chloride or Anti-Stipp significantly limited the appearance of bitter pit and breakdown.
\end{abstract}

\section{INTRODUCTION}

The interest in the significance of calcium in the supply of minerals to fruit trees has greatly increased since in the thirties it was found that one of the most frequent physiological apple diseases, bitter pit, is connected with a low content of this element in the fruits. Intensive research led to the establishment of numerous relations between the chemical composition of fruits and the incidence of still other physiological diseases of apples. It appeared that the traditional liming of soil is not sufficiently effective in the control of these diseases. The results of numerous investigations in many countries in the sixties ( $\mathrm{M}$ a $\mathrm{r} \mathrm{t} \mathrm{i}$ et al., 1960, J a c k s o n, 1962; S c h r e ve n et al., 1963; B e y e r s, 1963; D r a k e and $\mathrm{W}$ e e k s, 1967 and many others) and in later years (B a n g e r t h, 1973; S łow ik and Le gespi, 1974; S harples and J o h n s n, 1977; M a s o n, 1979; P e r r i n g, 1979; S h a r p le s, 1979; T e r b l a n c h e et al., 1979; W a 11 e r, 1979) and within a much smaller range in Poland (O s t r o w s k i, 1965; S a d o w s k i, 1967) demonstrated the high effectiveness of beyond-root fertilization with calcium nitrate or calcium chloride in the prevention of development of physiological apple diseases in storage.

B a n g e r t h (1973) reports a negative correlation between calcium content in apples and bitter pit incidence, 'Jonathan' spot, breakdown and watercore in apples. An increased incidence of apple scald was also noted on 
fruit with low calcium content. The view prevails that a better supply of calcium to the fruits can reduce these diseases. The reactions of various apple cultivars, however, show wide differences, as noted by numerous authors, among them O s t r ow s k i (1965) and S a d ow s k i (1967), S h a p le s and J o h n s o $n$ (1977). The causes of these diseases may be diverse, they do not result solely from poor supply of calcium to the fruits, and as regards bitter pit, they are not fully elucidated.

Calcium uptake by plants is affected by a number of factors such as: soil aeration and compactness, moisture, $\mathrm{pH}$ ( $\mathrm{T}$ e $\mathrm{r} \mathrm{b} \mathrm{la} \mathrm{n} \mathrm{c} \mathrm{h}$ e et al., 1979), the presence of other ions, especially $\mathrm{NH}_{4}^{+}, \mathrm{K}^{+}, \mathrm{Mg}^{++}$and $\mathrm{Al}^{+++}$(K i r k b y, 1979; K o t z e, 1979; S l o w i k, 1979). Excessive concentrations of these ions inhibit the process of Ca uptake by the roots.

It is generally believed that soils contain a sufficient amount of calcium to satisfy nutritional requirements of plants and that the symptoms of deficit of this element are rather due to a poor uptake and transport than to a lack of $\mathrm{Ca}$ in the soil. The weak mobility of $\mathrm{Ca}$ in plants and its translocation almost exclusively along vessels ( $\mathrm{F}$ e r g u s o $\mathrm{n}, 1979 \mathrm{~b}$ ) would cause local Ca deficits ( $\mathrm{F}$ e r g us o n, 1979a).

Rapid accumulation of calcium in fruits occurs in the first weeks after their setting (F e r g u s o n, 1979b; T r o m p, 1979) and lasts to about mid July. T r o m p (1979) suggests that calcium transport to fruits in the second half of the vegetation season is balanced by calcium excretion with water from the fruit. This occurs under conditions of water stress occurring in the course of daytime. $\mathrm{G}$ o o d e et al. (1978) reduced the occurrence of bitter pit of apples by watering the trees from June to mid September. Trials undertaken to apply antitranspirants in order to limit bitter pit in apples gave controversial results (S c h u m a c h e r et al., 1976; T e r b l a n c h e et al., 1979).

The most effective methods for increasing $\mathrm{Ca}$ content in fruits are: balanced fertilization, summer pruning, appropriate irrigation, and, above all, calcium salts supply by other pathways than the roots.

Spraying with calcium compounds is applied 3-8 times beginning with June and up to apple harvest, with the use of $\mathrm{Ca}\left(\mathrm{NO}_{3}\right)_{2}$ or $\mathrm{CaCl}_{2}$. The efficacy of these compounds in prevention of development of physiological apple diseases is rather similar (S ł o w i k and $\mathrm{L}$ e g a s p i, 1974), and it largely depends on the natural calcium content in the fruits ( $\mathrm{S}$ h a r p le s, 1979). For immersion of apples after the harvest only $\mathrm{CaCl}_{2}$ is used, usually in a 3-4 per cent concentration ( $M$ a s o $n, 1979$ ) and it does not cause impairment of the fruits, in spite of the high concentration used, contrary to calcium nitrate ( $\mathrm{S} \mathrm{h}$ a r p l e s, 1979). It has also been tried to increase calcium content in apples by its infiltration into the fruits under conditions of hypotension (J o h n s o n, 1979). 
The research conducted in the Institute of Pomology and Floriculture, concerning calcium nutrition of fruit trees was concentrated mainly on tests of new fertilization technologies which would increase the calcium content in the fruits, and at the same time effectively counteract the development of physiological diseases of apples in storage or cold storage.

\section{MATERIAL AND METHODS}

The experiments were started in 1977 and carried on for three years in an apple orchard with the cultivar 'Fantazja' at the Research Station Dąbrowice near Skierniewice. The experimental trees grow on three kinds of rootstock A 2 , M 7 and MM 106 at a spacing of 800 trees/ha.

Before the fruit harvest the trees were sprayed three times at two-week intervals with calcium nitrate solution $\left(\mathrm{Ca}\left(\mathrm{NO}_{3}\right)_{2} \cdot 4 \mathrm{H}_{2} \mathrm{O}\right)$ calcium chloride $\left(\mathrm{CaCl}_{2} \cdot 6 \mathrm{H}_{2} \mathrm{O}\right)$ and Anti-Stipp (Chemie Linz, Austria). All these chemicals were used in an equal concentration of 0.75 per cent. In the control combination the trees were not sprayed with calcium compounds at all.

For investigations on apple storage samples were taken in three replications. One replication consisted of a sample comprising about 120-150 fruits collected from three trees. The fruits were stored in a cold store at $0^{\circ} \mathrm{C}$ and relative air humidity $88-90$ per cent for three months. Then the apples were inspected and the appearance of physiological diseases and rotting were recorded. In 20 randomly chosen applies flesh firmness was determined (with a Magness-Taylor penetrometre), the colour was evaluated (percentage of fruit surface flushed red) and the basic colour of the skin (according to the colour scale). These fruits also served as material for chemical analyses.

After the period of storage 20 fruits were taken from each replication, free from any noticeable symptom of physiological disease and rotting and they were placed for five days at $+15^{\circ} \mathrm{C}$. After this period the flesh firmness of the apples, the basic colour and development of physiological diseases and rotting were once more determined.

The results were submitted to statistical analysis. For establishing the statistical significance Duncan's test was used at a 5 per cent significance level.

\section{RESULTS}

The severity of physiological diseases on the fruits of the cultivar 'Fantazja' depended to a high extent on the weather conditions in the particular years. The incidence of bitter pit was highest in the dry year 1979 (Table 1). The rootstock on which the trees were grafted exerted a much less conspicuous influence on the occurrence of bitter pit. The incidence of the latter was much lower on $\mathbf{M} 7$ rootstock as compared with that on A 2 and MM 106 (Table 1). 


\section{Ta b l e 1}

Incidence of bitter pit and breakdown on fruits of the 'Fantazja' cultivar in relation to the rootstock' and year

\begin{tabular}{|c|c|c|c|c|c|c|c|c|}
\hline \multirow{3}{*}{ Rootstock } & \multicolumn{8}{|c|}{ Year } \\
\hline & \multicolumn{2}{|r|}{1977} & \multicolumn{2}{|r|}{1978} & \multicolumn{2}{|r|}{1979} & \multicolumn{2}{|c|}{ Mean for, rootstock } \\
\hline & $\begin{array}{c}\text { bitter } \\
\text { pit } \\
\%\end{array}$ & $\begin{array}{c}\text { breakdown } \\
\%\end{array}$ & $\begin{array}{c}\text { bitter } \\
\text { pit } \\
\%\end{array}$ & $\begin{array}{c}\text { breakdown } \\
\%\end{array}$ & $\begin{array}{c}\text { bitter } \\
\text { pit } \\
\%\end{array}$ & $\begin{array}{c}\text { breakdown } \\
\%\end{array}$ & $\begin{array}{c}\text { bitter } \\
\text { pit } \\
\%\end{array}$ & $\begin{array}{c}\text { breakdown } \\
\%\end{array}$ \\
\hline A 2 & $7.0 \mathrm{bc}$ & $3.3 \mathrm{e}$ & $2.2 \mathrm{a}$ & $1.1 \mathrm{~cd}$ & $18.0 \mathrm{~d}$ & $0.1 \mathrm{ab}$ & $7.9 \mathrm{~b}$ & 1.1 \\
\hline M 7 & $2.0 \mathrm{a}$ & $1.6 \mathrm{cda}$ & $3.0 \mathrm{ab}$ & $3.0 \mathrm{de}$ & $9.0 \mathrm{c}$ & $0.0 \mathrm{a}$ & $4.3 \mathrm{a}$ & 1.0 \\
\hline MM 106 & $2.7 \mathrm{ab}$ & $0.8 \mathrm{bc}$ & $9.0 \mathrm{c}$ & 1.7 ode & $13.2 \mathrm{~cd}$ & $0.03 \mathrm{a}$ & $.7 .9 \mathrm{~b}$ & 0.6 \\
\hline
\end{tabular}

T a b l e 2

Some features of fruits of the 'Fantazja' cultivar sprayed with calcium solution in the successive years, means for three kinds of rootstock (A 2, M 7 and MM 106)

\begin{tabular}{ccccccc}
\hline & \multicolumn{6}{c}{ Feature } \\
\cline { 2 - 7 } Year & $\begin{array}{c}\text { Ca content } \\
\text { in flesh } \\
\text { mg/100gf.wt. }\end{array}$ & $\begin{array}{c}\text { K :Ca } \\
\text { ratio }\end{array}$ & $\begin{array}{c}\text { bitter pit } \\
\%\end{array}$ & $\begin{array}{c}\text { breakdown } \\
\%\end{array}$ & $\begin{array}{c}\text { fruit } \\
\text { firmness } \\
\text { pounds }\end{array}$ & $\begin{array}{c}\text { red flush } \\
\text { on fruits } \\
\% \text { of area }\end{array}$ \\
\hline 1977 & $2.1 \mathrm{~b}$ & $40.1 \mathrm{~b}$ & $3.6 \mathrm{a}$ & $1.8 \mathrm{~b}$ & $9.1 \mathrm{a}$ & $56 \mathrm{~b}$ \\
1978 & $1.9 \mathrm{a}$ & $45.1 \mathrm{c}$ & $4.5 \mathrm{a}$ & $1.9 \mathrm{~b}$ & $10.3 \mathrm{~b}$ & $46 \mathrm{a}$ \\
1979 & $2.8 \mathrm{c}$ & $26.2 \mathrm{a}$ & $13.2 \mathrm{~b}$ & $0.02 \mathrm{a}$ & $9.4 \mathrm{a}$ & $53 \mathrm{~b}$ \\
\hline
\end{tabular}

\section{Table 3}

Some features of fruits of 'Fantazja' cultivar, sprayed with calcium solution. Means for three kinds of rootstock (A 2, M 7 and MM 106) and for 3 years (1977, 1978 and 1979)

\begin{tabular}{|c|c|c|c|c|c|c|}
\hline \multirow[b]{2}{*}{ Combination } & \multicolumn{6}{|c|}{ Feature } \\
\hline & $\begin{array}{c}\text { Ca content } \\
\text { in flesh } \\
\mathrm{mg} / 100 \mathrm{gf} \text {.wt. }\end{array}$ & $\begin{array}{c}\mathrm{K}: \mathrm{Ca} \\
\text { ratio }\end{array}$ & $\begin{array}{c}\text { bitter pit } \\
\%\end{array}$ & $\begin{array}{c}\text { breakdown } \\
\%\end{array}$ & $\begin{array}{l}\text { fruit firm- } \\
\text { ness } \\
\text { pounds }\end{array}$ & $\begin{array}{l}\text { red flush } \\
\text { on fruits } \\
\% \text { of area }\end{array}$ \\
\hline Control & $1.9 \mathrm{a}$ & $42.6 \mathrm{c}$ & $14.9 \mathrm{~b}$ & $2.8 \mathrm{c}$ & 9.6 & $54 \mathrm{~b}$ \\
\hline $\begin{array}{c}\mathrm{Ca}\left(\mathrm{NO}_{3}\right)_{2} \\
3 \mathrm{x}\end{array}$ & $2.4 \mathrm{c}$ & $33.9 \mathrm{a}$ & $5.4 \mathrm{a}$ & $0.8 \mathrm{~b}$ & 9.6 & $48 \mathrm{a}$ \\
\hline $\begin{array}{r}\mathrm{CaCl}_{2} \\
3 \mathrm{x}\end{array}$ & $2.4 \mathrm{c}$ & $34.9 \mathrm{ab}$ & $3.5 \mathrm{a}$ & $0.2 \mathrm{a}$ & 9.5 & $53 \mathrm{~b}$ \\
\hline $\begin{array}{l}\text { Anti-Stipp } \\
3 x\end{array}$ & $2.2 \mathrm{~b}$ & $37.1 \mathrm{~b}$ & $4.7 \mathbf{a}$ & $0.5 \mathrm{ab}$ & 9.4 & $51 \mathrm{ab}$ \\
\hline
\end{tabular}


Ta b le 4

Influence of spraying with calcium solution on $\mathrm{Ca}$ content and $\mathrm{K}: \mathrm{Ca}$ ratio in fruits of 'Fantazja' cultivar on various rootstock, means for 3 years

\begin{tabular}{|c|c|c|c|c|c|c|c|c|}
\hline \multirow{2}{*}{ Combination } & \multicolumn{6}{|c|}{ Rootstock } & \multirow{2}{*}{$\begin{array}{c}\text { Mean Ca } \\
\text { content }\end{array}$} & \multirow{2}{*}{$\begin{array}{c}\text { Mean } \mathrm{K}: \mathrm{Ca} \\
\quad \text { ratio }\end{array}$} \\
\hline & \multicolumn{2}{|c|}{ A 2} & \multicolumn{2}{|c|}{ M 7} & \multicolumn{2}{|c|}{ MM 106} & & \\
\hline Control & $1.99 \mathrm{ab}$ & $41.0 \mathrm{de}$ & $1.81 \mathrm{a}$ & $45.6 \mathrm{e}$ & $2.00 \mathrm{ab}$ & $41.2 \mathrm{de}$ & $1.93 \mathrm{a}$ & $42.6 \mathrm{c}$ \\
\hline $\begin{array}{r}\mathrm{CaCl}_{2} \\
3 \times\end{array}$ & $2.43 \mathrm{~cd}$ & $35.8 \mathrm{bc}$ & $2.33 \mathrm{~cd}$ & $34.8 \mathrm{abc}$ & $2.41 \mathrm{~cd}$ & 34.0 & $2.39 \mathrm{c}$ & $34.9 \mathrm{ab}$ \\
\hline $\begin{array}{c}\text { Anti-Stipp } \\
3 x\end{array}$ & $208 \mathrm{~b}$ & $44.1 \mathrm{de}$ & $2.32 \mathrm{~cd}$ & $33.7 \mathrm{ab}$ & $2.30 \mathrm{c}$ & 33.7 & $2.23 \mathrm{~b}$ & $37.1 \mathrm{~b}$ \\
\hline
\end{tabular}


The most important features of fruits of the 'Fantazja' cultivar in the particular years are shown in Table 2. Calcium content in the fruit flesh was found to be lowest in 1978 and highest in 1979 . The $\mathrm{K}:$ Ca ratio, on the contrary, was highest in 1978 and lowest in 1979, although in the latter year symptoms of bitter pit were most severe.

Spraying with calcium solution significantly raised the calcium level in the fruit flesh (Table 3). All solutions used for spraying significantly restricted the occurrence of bitter pit and breakdown. The colouring of fruits was significantly impaired by spraying with calcium nitrate as compared with fruits sprayed with calcium chloride or the control ones.

Calcium content significantly increased in the flesh of fruits sprayed with calcium nitrate or chloride on all three tested of rootstock as compared with that in the control (Table 3 ). This was particularly noticeable in the mean values for all the three kinds of rootstock (Table 4). Differences were not found in calcium content in fruits sprayed with calcium nitrate or chloride. The $\mathrm{K}: \mathrm{Ca}$ ratio was highest in all cases in the control combinations, the fruits sprayed with Anti-Stipp from rootstock A 2 excepted.

\section{CONCLUSIONS}

1. The investigations confirmed the usefulness of applying calcium beyond the roots for controlling the occurrence of bitter pit and breakdown.

2. The influence of the weather in the given season was more pronounced than that of the rootstock on the incidence of physiological diseases on the fruits of the cultivar 'Fantazja'.

3. Calcium content in the flesh of fruits sprayed with calcium nitrate or chloride increased significantly as compared with that in the control combination.

\section{REFERENCES}

B a n g e is t h F., 1973. Investigations upon Ca - related physiological disorders. Phytopath. Z. 77: 20-37.

B e y e r s E., 1963. Control of bitter pit and other disorders of apples with calcium sprays. Deciduous Fruit Grower. 13.

D r a k e M., W e e k s W. D., 1967. Foliar calcium sprays for bitter pit control. Fruit Notes (Dept. Pl. Soil Sci., Univ. Masš) no 2.

F e r g u s o n J. B., 1979a. The movement of calcium in non-vascular tissue of plants. Commun. in Soil Science and Plant Analysis 10: 217-224. 
F e r g u s o n J. B., 1979b. The uptake and transport of calcium in the fruit tree. Conference on mineral nutrition and fruit quality of temperate zone fruit trees. Canterbury U.K. April 1979. 21: 183-192.

G o o d e J. E., H i g g s K. H., H y r y c z K. J., 1978. Nitrogen and water effects on the nutrition, growth, crop yield and fruit quality of orchard-grown Cox's Orange Pippin apple trees. Journal Hortic. Sci. 53: 295-306.

J a c k s o n D. J., 1962. The effects of calcium and other minerals on the incidence of bitter pit in Cox's Orange apples. New Zealand Jour. Agric. Res., 5.

J o h n s o n D. S., 1979. New techniques in the post-harvest treatment of apple fruits with calcium salats. Commun. in Soil Science and Plant Analysis 10: 373-382.

K i r k b y E. A., 1979. Maximizing calcium uptake by plant. Commun. in Soil Sci. and Plant Analysis $10(1,2): 89-114$.

$\mathrm{K}$ o $\mathrm{z}$ e W. A. G., 1979. Ionic Interactions in the uptake and transport of calcium by apple seedlings. Commun. in Soil Sci. and Plant Analysis 10 (1, 2): 115-128.

Marti n D., L e w is T. L., C e r n y J., 1960. Bitter pit in the apple variety Cleopatra in Tasmania in relation to calcium and magnesium. Australian Jour. Agric. Res., 11.

M a s o n J. L., 1979.' Increasing calcium content of calcium-sensitive tissues. Commun. in Soil Science and Plant Analysis 10: 349-371.

O s t r o w s k i W., 1965. Badania nad właściwościami fizycznymi i chemicznymi jabłek porażonych gorzką plamistością podskórną oraz próby zmniejszania strat powodowanych przez tę chorobę. Zeszyty Nauk. WSR Szczecin 19: 3-68.

P e r r i n g M. A., 1979. The effects of environment and cultural practices on calcium concentration in the apple fruit. Commun. in Soil Science and Plant Analysis 10: 279-293.

S a d o w s k i A., 1967. Niektóre czynniki wpływające na występowanie gorzkiej plamistości podskórnej jabłek i możliwości jej zapobiegania. Instytut Sadownictwa. Skierniewice 1967. 1-104.

S c h r e ve n A.C., v a n d e r B o o n J., D a s A., 1963. Bestrijding van stip in apples Cox's Organge Pippin. Fruitteelt, 53.

S chum a che r R., Fa n k ha us e r F., S t a d le r W., 1976. Versuche mit Calcium chlorid. Antitranspiranten und Borsäure zur Verminderung der Stippebildung. Schweiz, Zeitschrif + für Obst- und Weinbau 112: 300-304.

$\mathrm{S}$ h a r p l e s R. O., 1979. The influence of orchard nutrition on the storage quality of apples and pears grown in the United Kingdom. Conference on mineral nutrition and fruit quality of temperate zone fruit trees. Canterbury U.K. April 1979. 3: 17-28.

$\mathrm{S}$ h a r p l e s R. O., J o h n s o n D. S., 1977. The influence of calcium on senescence changes in apple. Annals Applied Biology 85: 450-453.

S 1 o w i k K., 1979. Effects of environmental and cultural practices on calcium nutrition of fruit trees. Commun. in Soil Science and Plant Analysis 10: 295; 302.

S l o w i k K., L e g a s p i G u z m a n A., 1974..Aspersiones tardias de calcio en manzano cv. Rayada para controlar la mancha amarga, "Bitter Pit." V Congreso CIAMEC 15-19 April, Oaxtepec, Mexico 1974.

T e r b l a n c h e J. H., G u r ge n K. H., H a s e b e c k J., 1979. An integrated approach to orchard nutrition and bitter pit control. Conference on mineral nutrition and fruit quality of temperate zone fruit trees. Canterbury U.K. April 1979. 8: 71-82.

T r o m p J., 1979. Take intake curve for calcium into apple fruits under various environmental conditions. Commun. in Soil Science and Plant Analysis 10: 325-335.

W a 11 e r W. M., 1979. Use of apple analysis. Conference on mineral nutrition and fruit quality of temperate zone fruit trees. Canterbury U.K. April 1979. 66: 383-394. 


\section{Nawożenie pozakorzeniowe jabłoni wapniem}

S t reszczen i e

W latach 1977-1979 przeprowadzono badania nad wpływem opryskiwania jabloni odmiany 'Fantazja' roztworami za wierającymi wapn': azotanem wapnia $\left(\mathrm{Ca}\left(\mathrm{NO}_{3}\right)_{2} \cdot 4 \mathrm{H}_{2} \mathrm{O}\right)$, chlorkiem wapnia $\left(\mathrm{CaCl}_{2} \cdot 6 \mathrm{H}_{2} \mathrm{O}\right)$ i preparatem Anti-Stipp na występowanie chorób fizjologicznych na jabłkach, zawartość wapnia w miąższu owoców oraz innych cech owoców. Badania prowadzono na trzech podkładkach: A 2, M 7 i MM 106, przy czym drzewa we wszystkich przypadkach rosły w zagęszceniu $800 \mathrm{drzew} / \mathrm{ha}$. Trzykrotne opryskiwanie azotanem wapnia, chlorkiem wapnia lub preparatem Anti-Stipp istotnie ograniczało występowaṇie gorzkiej plamistości podskórnej i rozpadu. Istotne pogorszenie wybarwienia się wystąpilo na owocach opryskiwanych azotanem wapnia w porównaniu z kombinacją kontrolną lub opryskiwaną chlorkiem wapnia. Nie stwierdzono różnic w zawartości wapnia w owocach opryskiwanych azotanem wapnia lub chlorkiem wapnia. 